\title{
Current status of granulocyte-macrophage colony-stimulating factor in the immunotherapy of melanoma
}

\author{
Howard L Kaufman ${ }^{1 *}$, Carl E Ruby ${ }^{2}$, Tasha Hughes ${ }^{2}$ and Craig L Slingluff $\mathrm{Jr}^{3}$
}

\begin{abstract}
In 2012, it was estimated that 9180 people in the United States would die from melanoma and that more than 76,000 new cases would be diagnosed. Surgical resection is effective for early-stage melanoma, but outcomes are poor for patients with advanced disease. Expression of tumor-associated antigens by melanoma cells makes the disease a promising candidate for immunotherapy. The hematopoietic cytokine granulocyte-macrophage colony-stimulating factor (GM-CSF) has a variety of effects on the immune system including activation of T cells and maturation of dendritic cells, as well as an ability to promote humoral and cell-mediated responses. Given its immunobiology, there has been interest in strategies incorporating GM-CSF in the treatment of melanoma. Preclinical studies with GM-CSF have suggested that it has antitumor activity against melanoma and can enhance the activity of anti-melanoma vaccines. Numerous clinical studies have evaluated recombinant GM-CSF as a monotherapy, as adjuvant with or without cancer vaccines, or in combination with chemotherapy. Although there have been suggestions of clinical benefit in some studies, results have been inconsistent. More recently, novel approaches incorporating GM-CSF in the treatment of melanoma have been evaluated. These have included oncolytic immunotherapy with the GM-CSF-expressing engineered herpes simplex virus talimogene laherparepvec and administration of GM-CSF in combination with ipilimumab, both of which have improved patient outcomes in phase 3 studies. This review describes the diverse body of preclinical and clinical evidence regarding use of GM-CSF in the treatment of melanoma.
\end{abstract}

Keywords: Granulocyte macrophage-colony stimulating factor, GM-CSF, Melanoma, Cellular immunotherapy

\section{Introduction}

In 2012, it was estimated that 9180 people in the United States would die from melanoma and more than 76,000 new cases would be diagnosed [1]. The primary treatment for melanoma, excision of the malignancy, is highly effective in early-stage disease but is not a meaningful option for metastatic disease except in patients with solitary metastases or limited-volume disease [2]. For patients with advanced disease, cytotoxic chemotherapy has a limited role and curative potential in $<1 \%$ of patients. For BRAFmutant patients, treatment with vemurafenib, dabrafenib, and/or tremetinib have high rates of objective response,

\footnotetext{
* Correspondence: howard.kaufman@rutgers.edu

${ }^{1}$ Rutgers Cancer Institute of New Jersey, 195 Little Albany Street, New

Brunswick, NJ 08901, USA

Full list of author information is available at the end of the article
}

but median duration of response is typically $\sim 6-8$ months, after which rapid disease progression is common [2]. However, some patients with melanoma respond to immunotherapy with durable responses, and thus immunotherapy shows substantial promise for further improving durable control of advanced melanoma.

Expression of tumor-associated antigens by melanoma cells makes the disease a promising candidate for immunotherapy [3]. The potential for immunotherapy in melanoma has been demonstrated by improved outcomes among patients with stage III melanoma receiving interferon- $\alpha 2 b$ [4] and patients with metastatic melanoma receiving the anti-cytotoxic T-lymphocyte antigen 4 (CTLA-4) antibody ipilimumab alone or in combination 
with a gp100 peptide vaccine or dacarbazine [5,6], as well as by durable complete responses with high-dose interleukin-2 [7] and high response rates after adoptive T cell transfer therapies [8].

The hematopoietic cytokine granulocyte-macrophage colony-stimulating factor (GM-CSF) has been investigated as a monotherapy, and as a component of combination therapies for melanoma. Preclinical evidence has suggested that GM-CSF may have antitumor effects, but results from clinical trials evaluating GM-CSF present a complex picture. This review evaluates evidence regarding use of GM-CSF in melanoma and potential future strategies in this setting.

\section{Review}

\section{Immunobiology of GM-CSF}

GM-CSF was identified as a factor responsible for expansion and activation of granulocytes and macrophages, but has since been found to have many direct and indirect effects on multiple cell types, including cell proliferation, maturation, and survival (Figure 1A) [9]. GM-CSF plays a critical role in development and maturation of dendritic cells (DCs) and proliferation and activation of T cells, linking the innate and acquired immune response [10]. In mice, increased numbers of eosinophils, monocytes, macrophages, and lymphocytes were observed in the draining lymph node in response to treatment with irradiated melanoma cells expressing GM-CSF, resulting in a sustained antitumor response [11]. GM-CSF has also been shown to favor expansion of DC1 populations [12,13] and to increase DC-mediated responses to tumor cells (Figure 1B) [14]. In vitro studies using human myeloid leukemia cells suggest that, in addition to promoting antigen presentation, GM-CSF directs these cells toward a DC phenotype $[15,16]$. The role of GM-CSF in neutrophil proliferation and survival led to its use in amelioration of neutropenia following induction chemotherapy in elderly patients with acute myeloid leukemia [17].

\section{Studies evaluating GM-CSF in preclinical models of melanoma}

The immune adjuvant properties of GM-CSF led to numerous preclinical studies assessing the ability of GM-CSF to inhibit tumor growth and/or mediate tumor regression. In a seminal study, a panel of recombinant retroviral vectors expressing various cytokines, co-stimulatory molecules, or adhesion molecules were used to infect murine B16 melanoma cells. Infected cells were then irradiated and injected subcutaneously into immune-competent hosts, followed by a subsequent challenge with wild-type B16 cells [11]. The GM-CSF-secreting tumor vaccines conveyed 90\% protection, whereas vaccines expressing interleukin-2 and interferon- $\gamma$ failed to mediate antitumor protection [11]. Additionally, analysis of the vaccination site revealed an influx of dividing monocytes and granulocytes, with a coincident increase in lymphocytes in tumor-draining lymph nodes, suggesting direct augmentation of antigen presentation and T-cell priming against the tumor [11].

Exogenously administered GM-CSF has been shown to augment antitumor immunity Mice immunized with an HIV envelope peptide vaccine plus GM-CSF exhibited increased cytotoxic T lymphocyte (CTL) activity compared with vaccine alone or vaccine with interleukin-2 [18]. Studies using a tumor-associated antigen vaccine (neu), in combination with GM-CSF, produced increased neu-specific antibodies alongside an enhanced CTL response $[19,20]$. However, tumor protection was ultimately dependent on a cell-mediated response since depletion of $\mathrm{CD}^{+} \mathrm{T}$ cells abrogated tumor regression.

Genetically modified vaccines can generate protective anti-melanoma immune responses in animal models [21]. B16 tumor lines expressing bioactive levels of murine GM-CSF have been generated and assessed [11,21,22]. Levels of GM-CSF at the site of GM-CSF-expressing tumor transplantation remain elevated for days, whereas GM-CSF dissipated rapidly after injection of irradiated tumor with recombinant GM-CSF [22]. The pharmacokinetic longevity associated with the vaccine correlated with both increased DC infiltration and tumor protection against wild-type tumors [22].

Oncolytic immunotherapy with modified herpes simplex viruses (HSV) and vaccinia viruses expressing GM-CSF have also shown promise. These vectors have elicited tumor responses in mice when injected directly into tumor lesions [23-25]. In a murine melanoma model, a temperaturesensitive strain of HSV encoding murine GM-CSF significantly reduced Harding-Passey melanoma tumor growth and improved survival of tumor-bearing mice [25]. Similarly, preclinical studies demonstrated a potent lytic effect against lesions injected with the GM-CSF-expressing oncolytic HSV talimogene laherparepvec (T-VEC; formerly Oncovex $^{\text {GM-CSF }}$ [ [26]. Notably, when virus expressing GMCSF was employed, regression of uninjected, distant lesions was enhanced compared with a regression observed with a control virus not expressing GM-CSF.

The combination of GM-CSF-secreting tumor vaccines with other immunotherapies is another potentially promising approach. Antibodies that block the co-inhibitory T-cell molecules CTLA-4 and PD-1 plus GM-CSF have boosted immune responses against melanomas [5,27-31]. Additionally, activation of co-stimulatory molecules (CD80, CD86, CD137), exogenous cytokine administration (interleukin-2, interferon- $\gamma$ ), and blockade of tumor angiogenesis can inhibit melanoma progression when combined with GMCSF-expressing vaccines [32-36]. These preclinical studies strongly suggest that the combination of GM-CSF-based tumor vaccines with immunomodulatory agents has potential for clinical use. 
Figure 1 Immunobiologic effects of GM-CSF. (A) Effects of GM-CSF on cells of the immune system. (B) Effects of GM-CSF on dendritic cells and $T$ cells in the tumor microenvironment. 


\section{Clinical trials evaluating exogenously administered GM-CSF in patients with melanoma}

Given the evidence of antitumor activity in preclinical models of melanoma, there has been interest in using GM-CSF to improve outcomes in the clinical setting. Numerous studies have evaluated use of recombinant GM-CSF in completely resected stage III/IV melanoma patients. Data from these studies, however, have been inconsistent.

\section{GM-CSF as an adjuvant therapy}

GM-CSF has been evaluated as an adjuvant, systemic monotherapy following regional lymphadenectomy, to prevent or to delay recurrence in high-risk stage III patients (Table 1 ). In a phase 2 study, there were statistically significant improvements in survival among patients with stage III/IV disease $(P=0.04$ and $P<0.001$, respectively) receiving GM-CSF $\left(125 \mu \mathrm{g} / \mathrm{m}^{2}\right.$ daily for 14 consecutive days in 28-day cycles up to 1 year) compared with historical controls [37]. A subsequent single-arm study using the same dosing regimen evaluated treatment with GMCSF over 3 years and reported a 5-year survival rate of $60 \%$, with 5-year disease-free survival (DFS) of $67 \%$ and $40 \%$ for patients with stage III and IV disease, respectively [38]. The effect of GM-CSF on DC has been proposed as a mechanism for supporting antitumor immunity; consistent with this hypothesis, treatment with recombinant GM-CSF has increased mature DCs in melanoma patients [39]. A randomized study of recombinant GMCSF $\left(125 \mu \mathrm{g} / \mathrm{m}^{2}\right.$ daily for 14 consecutive days in 28-day cycles) versus placebo in patients with completely resected stage IIIB/IIIC/IV or mucosal melanoma, there was a trend toward improvement in DFS although it did not reach statistical significance (11.5 vs 9.2 months; HR, $0.88 ; P=0.14)$, and no improvement in overall survival (OS; 69.6 vs 62.4 months; HR, 0.96; $P=0.78$ ) [40]. However, an improvement in DFS $(\mathrm{HR}, 0.74 ; P=0.04)$ and a trend toward improved OS (HR, 0.72; $P=0.07$ ) was observed in stage IV patients $(n=258)$ [40].

\section{GM-CSF as intratumoral monotherapy}

Several small studies have evaluated GM-CSF administered as a monotherapy by direct injection into metastatic lesions (Table 2). Clinical responses in two of these studies were modest, with only one partial response (PR) and no complete response (CR) reported $[44,45]$. In contrast, a study using perilesional injection of GM-CSF $(400 \mu \mathrm{g} / \mathrm{d}$ over 5 days $)$ to treat metastatic melanoma described reduced lesion size in $6 / 7$ patients and a reduction in cutaneous metastases in $5 / 7$ patients [46]. Three patients were still alive at 5-years follow-up; a fourth died tumor-free at age 93. In these studies, there was evidence of increases in DC and T-cell counts and infiltration at injected sites, and in some cases at uninjected sites, suggesting an immunologic effect of GM-CSF injection [44-46]. Other studies using novel methods (such as aerosolization and immunoembolization) to delivering GM-CSF to melanoma metastases at sites that are not readily injectable have met with mixed results (Table 2) [47-50].

\section{GM-CSF in combination with chemotherapy}

A number of early-phase clinical studies have evaluated GM-CSF in conjunction with chemotherapy (Table 3). These studies were typically small with a single-arm design and used a variety of different drug regimens and dosing schedules; thus, as a whole, they are difficult to interpret. Clinical efficacy in studies varied widely, with response rates ranging from no response to $>40 \%$ [53-58]. It is worth noting that several of the studies reporting high overall response rates also reported significant increases in T-cell, DC, macrophage, or natural killer-cell populations following treatment [53,55,58]. One study evaluating a chemotherapy regimen of dacarbazine, interferon- $\alpha 2 b$, interleukin-2, and tamoxifen with three doses of GM-CSF reported a dose-response effect with increasing exposure to GM-CSF via administration over a greater number of days $(P=0.016)$ [59].

Table 1 Clinical studies evaluating adjuvant GM-CSF in patients with surgically resected melanoma

\begin{tabular}{|c|c|c|c|c|}
\hline Citation & Evaluable patients & GM-CSF dose schedule & Control & Clinical response \\
\hline Spitler et al. [37] & 48 & $125 \mu \mathrm{g} / \mathrm{m}^{2}$ for $14 \mathrm{~d}, 28-\mathrm{d}$ cycles, for $1 \mathrm{y}$ & Historical & OS: $37.5 \mathrm{mo}$ \\
\hline Markovic et al. [41] & 70 (Stage IV) 149 (Stage III) & $\begin{array}{l}125 \mu \mathrm{g} / \mathrm{m}^{2} \text { for } 14 \mathrm{~d}, 28-\mathrm{d} \text { cycles, } \\
\text { for } 1 \text { y } 125 \mu \mathrm{g} / \mathrm{m}^{2} \text { for } 14 \mathrm{~d} \text {, 28-d cycles, for } 1 \text { y }\end{array}$ & Observation & $\begin{array}{l}\text { OS: } 6.6 \text { y (GM-CSF) vs } 6.8 \text { y (control) } \\
\text { OS: } 8.6 \text { (GM-CSF) vs } 5.2 \text { y (control) }\end{array}$ \\
\hline Isla et al. [42] & 24 & $150 \mathrm{mg} / \mathrm{d}$ for 2 y & None & DFS at $1 \mathrm{y}: 88.8 \%$ \\
\hline Elias et al. [43] & 45 & $\begin{array}{l}125 \mu \mathrm{g} / \mathrm{m}^{2} \text { for } 14 \mathrm{~d} \text {, then } \mathrm{IL}-29 \times 10^{6} \mathrm{IU} / \mathrm{m}^{2} \\
\text { for } 4 \mathrm{~d}, / 28-\mathrm{d} \text { cycle, } \pm \text { autologous vaccine }\end{array}$ & None & $\begin{array}{l}\text { DFS at } 15.9 \text { mo: } 60 \% \text { OS at } 21 \text { mo: } \\
64 \% \text { ( } 21 \text { mo follow-up) }\end{array}$ \\
\hline Spitler et al. [38] & 98 & $125 \mu \mathrm{g} / \mathrm{m}^{2}$ for $14 \mathrm{~d}, 28-\mathrm{d}$ cycles, for 3 y & None & DFS: 1.4 y 5-y survival: 60\% \\
\hline Lawson et al. [40] & 743 & $250 \mu \mathrm{g} / \mathrm{m}^{2}$ for $14 \mathrm{~d}, 28-\mathrm{d}$ cycles, for $1 \mathrm{y}$ & Placebo & $\begin{array}{l}\text { OS: } 62.4 \text { mo for placebo vs. } \\
69.6 \text { mo for GM-CSF (HR, 0.96) } \\
\text { DFS: } 9.2 \text { mo for placebo vs. } 11.5 \text { mo } \\
\text { for GM-CSF (HR, 0.88) }\end{array}$ \\
\hline
\end{tabular}




\begin{tabular}{|c|c|c|c|c|}
\hline Citation & $\begin{array}{l}\text { Evaluable } \\
\text { patients }\end{array}$ & GM-CSF dose schedule & Other agents & Clinical response $\frac{\vec{\partial}}{\omega}$ \\
\hline Schacter et al. [53] & 40 & $20 \mu \mathrm{g} / \mathrm{m}^{2}$ once daily for $7 \mathrm{~d}$ every $3 \mathrm{wk}$ & $\begin{array}{l}\text { BCNU, CDDP, DTIC, tamoxifen, } \\
\text { IFN-a }\end{array}$ & 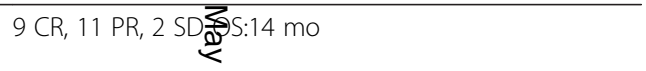 \\
\hline Gajewski et al. [60] & 7 & $5 \mu \mathrm{g} / \mathrm{kg}$ for $6 \mathrm{~d}$ & DTIC, CDDP, IL-2, IFN-a & 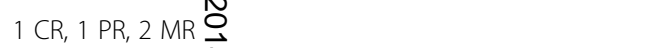 \\
\hline Gibbs et al. [61] & 60 & $250 \mu \mathrm{g} / \mathrm{m}^{2}$ for $20 \mathrm{~d}, 28-\mathrm{d}$ cycle & $\mathrm{TMZ}, \mathrm{CDDP}, \mathrm{IL}-2, \mathrm{IFN}-\mathrm{a}$ & 1 CR, 11 PR Mediäg OS: 11 mo \\
\hline \multirow[t]{3}{*}{ Vaughan et al. [59] } & \multirow[t]{3}{*}{19} & Arm 1: $450 \mu \mathrm{g} / \mathrm{m}^{2}$ on days $4,5,15$, and 16 & \multirow[t]{3}{*}{ DTIC, CDDP, IL-2, IFN-a, TAM } & \multirow{3}{*}{ 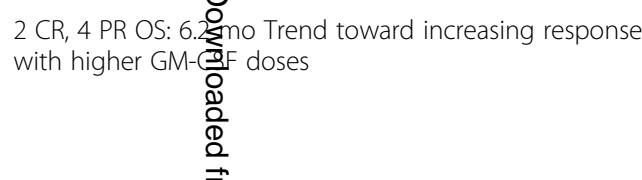 } \\
\hline & & $\begin{array}{l}\text { Arm 2: } 450 \mu \mathrm{g} / \mathrm{m}^{2} \text { on days } 4,5,15,16 ; 225 \mu \mathrm{g} / \mathrm{m}^{2} \\
\text { on days } 6-10 \text { and } 17-21,28-\mathrm{d} \text { cycle }\end{array}$ & & \\
\hline & & Arm 3: $450 \mu \mathrm{g} / \mathrm{m}^{2}$ on days $4-10$ and $15-21,28-\mathrm{d}$ cycle & & \\
\hline Gong et al. [62] & 30 & $\begin{array}{l}5 \mu \mathrm{m} / \mathrm{kg} \text { (first } 25 \text { patients) or } 450 \mu \mathrm{g} / \mathrm{m}^{2} \\
\text { (last } 8 \text { patients) for } 6 \mathrm{~d}\end{array}$ & DTIC, CDDP, IL-2, IFN- $a$ & 3 CR, 4 PR, 6 MR, $\underset{2}{\frac{\vec{Q}}{3}}$ SD Median OS: 15 mo \\
\hline Groenewegen et al. [63] & 31 & $2.5 \mu \mathrm{g} / \mathrm{kg}$ for $10 \mathrm{~d}$ & DTIC, IL-2, IFN-a & 4 CR, 6 PR Media蛋 OS: 8 mo 1-y survival: 22\% \\
\hline De Gast et al. [64] & 74 & $2.5 \mu \mathrm{g} / \mathrm{kg}$ for $12 \mathrm{~d}$ & $\mathrm{TMZ}, \mathrm{IL}-2, \mathrm{IFN}-\mathrm{a}$ & 4 CR, 19 PR, 13 S 鹿OS: 8.3 mo 1-y survival: $41 \%$ \\
\hline Smith et al. [65] & 8 & 125 and $250 \mu \mathrm{g} / \mathrm{m}^{2} / \mathrm{d}$ for $7 \mathrm{~d}$ every $2 \mathrm{wk}, 28-\mathrm{d}$ cycle & $\mathrm{IL}-2$ & $O C R, O P R \quad \frac{0}{3}$ \\
\hline Fruehauf et al. [54] & 10 & $250 \mu \mathrm{g} / \mathrm{m}^{2}$ for $11 \mathrm{~d}$ & DOX, VIN & 0 CR, 5 PR Mediåtime to progression: 8 mo \\
\hline Lewis et al. [66] & 71 & $250 \mu \mathrm{g} / \mathrm{m}^{2}$ for $20 \mathrm{~d}, 28-\mathrm{d}$ cycle & TMZ, CDDP, IFN-a, IL-2 & 0 CR, 10 PR Medi⿸尹口 OS: 8.6 mo \\
\hline Weber et al. [67] & 31 & $125 \mu \mathrm{g} / \mathrm{m}^{2}$ for $12 \mathrm{~d}, 28-\mathrm{d}$ cycle & $\mathrm{TMZ}, \mathrm{IL}-2, \mathrm{IFN}-\mathrm{a}$ & 4 CR, 4 PR, 7 SD ब्ञs: 13.1 mo \\
\hline Jin et al. [55] & 18 & $175 \mu \mathrm{g} / \mathrm{m}^{2}$ for $4 \mathrm{~d}, 21-\mathrm{d}$ cycle & DTIC, IL-2 & $4 \mathrm{CR}, 8 \mathrm{PR}$ \\
\hline \multirow[t]{2}{*}{ O’Day [56] } & \multirow[t]{2}{*}{131} & $\begin{array}{l}\text { Induction: } 500 \mu \mathrm{g} / \mathrm{d} \text { for } 10 \mathrm{~d} \text { or once daily until } \\
\text { ANC }>5000 / \mu \mathrm{L}\end{array}$ & $\begin{array}{l}\text { Induction: VBL, CDDP, DTIC, IL-2, } \\
\text { IFN-a }\end{array}$ & 10 CR, 47 PR, 38 ST్GMMedian OS: 13.5 mo 1-y survival: 57\% \\
\hline & & Maintenance: $250 \mu \mathrm{g} / \mathrm{d}$ for $14 \mathrm{~d}$ & Maintenance: IL-2 & No \\
\hline Gunturu et al. [68] & 18 & $\begin{array}{l}250 \mu \mathrm{g} / \mathrm{m}^{2} \text { from day } 8 \text { until } \mathrm{AGC}>5000 \text { cells/ } \mu \mathrm{L} \text { on } 2 \\
\text { consecutive days }\end{array}$ & CTX, FLU, MESNA, IL-2 & $1 \mathrm{CR}, 3 \mathrm{PR}$ \\
\hline Locke et al. [57] & 14 & $250 \mu \mathrm{g} / \mathrm{m}^{2}$ until WBC $>30000 / \mu \mathrm{L}$ or for $10 \mathrm{~d}, 21-\mathrm{d}$ cycle & OX, DOX & 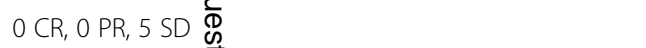 \\
\hline Lutzky et al. [69] & 30 & $125 \mu \mathrm{g} / \mathrm{m}^{2}$ for $35 \mathrm{~d}$ & $\mathrm{IL}-2$ & o CR, 4 PR, 8 SD dian OS: 10.7 mo 1-y survival: 32.5\% \\
\hline \multicolumn{5}{|c|}{ 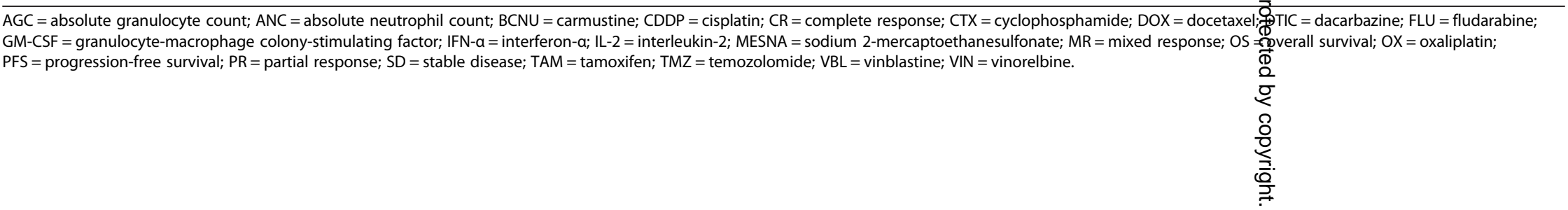 } \\
\hline
\end{tabular}




\section{GM-CSF as an adjuvant with cancer vaccines}

Given the significant body of evidence from preclinical studies $[11,18,20,21,70]$, GM-CSF has been evaluated as an adjuvant to cancer vaccines in a number of clinical studies. Several approaches to administering GM-CSF as an adjuvant have been employed, including coadministration with the vaccine [71-74], injection at the vaccination site [75,76] systemic administration [77,78], and administration of a plasmid/viral vector encoding GMCSF $[79,80]$. The dose of GM-CSF administered as an adjuvant is typically less than the recommended overall weekly dose of $250 \mu \mathrm{g} / \mathrm{m}^{2} /$ day for 21 days for use in myeloid reconstitution after autologous bone marrow transplantation [17].

In contrast to data from murine studies, the adjuvant effect of GM-CSF in human trials is inconsistent. In a study that evaluated coadministration of GM-CSF with multipeptide (including gp100 and tyrosinase peptides) melanoma vaccines incorporating GM-CSF and incomplete Freund's adjuvant (IFA) in patients with advanced melanoma, there was a high $\mathrm{T}$-cell response rate and a correlation between $\mathrm{T}$-cell reactivity to the melanoma peptides and clinical outcome [72]. GM-CSF combined with IFA as an adjuvant for a vaccine containing 12 melanoma peptides resulted in a similar immunologic response in patients with resected stage III/IIIB/IV melanoma [74]. Similarly, systemic administration of GM-CSF following a peptide vaccination augmented $\mathrm{T}$-cell response in three patients with advanced melanoma [77]. However, in a study that evaluated intradermal vaccination with tyrosinase peptides followed by intradermal GM-CSF, detectable T-cell responses were observed in only 4/15 (27\%) evaluable patients [76].

Although results from these studies have suggested that administration of adjuvant GM-CSF might improve immune responses, none included control groups. Recently, clinical trials including controls have evaluated effects of GM-CSF administered locally at the vaccination site (Table 4). In a phase 1 study comparing different adjuvant strategies, vaccination with tyrosinase peptide plus GMCSF or keyhole limpet hemocyanin (KLH) did not induce greater immune responses compared with vaccination with peptide alone, although combination with GM-CSF plus KLH had a moderate adjuvant effect [75]. Two recent randomized prospective trials suggested that addition of GM-CSF to melanoma vaccines did not improve cellular immune responses and, indeed, may have had negative effects [71,81]. Notably, both studies combined GM-CSF with another adjuvant (IFA or BCG) which may have influenced the immune response. The inconsistent effect of GM-CSF on immune responses to vaccines may be due in part to competing effects inducing dendritic cell maturation on one hand, and inducing myeloid suppressor cells on the other. A recent phase 2, randomized controlled trial (E1696) evaluated treatment of advanced melanoma with multipeptide vaccine alone or with subcutaneous interferon- $\alpha$, GM-CSF, or interferon- $\alpha$ plus GM-CSF $[78,82]$. Consistent with results of studies evaluating administration of GM-CSF at the vaccine site, no significant improvement in T-cell or clinical response was observed with interferon- $\alpha$ and/or GM-CSF administration with vaccination $[78,82]$.

Results from clinical studies evaluating GM-CSF as an adjuvant to melanoma vaccines suggest the biologic effects of GM-CSF are complex and can be influenced by numerous factors. GM-CSF administered with a heat shock protein vaccine has been implicated in the induction of myeloid-derived suppressor cells (MDSC) in melanoma patients [83]. On the other hand, daily subcutaneous administration of GM-CSF $\left(125 \mu \mathrm{g} / \mathrm{m}^{2}\right.$ for 14 days in 28 -day cycles) increased circulating mature DC but did not increase MDSC in melanoma patients [39]. It has been suggested that negative immunologic effects of GM-CSF may be associated primarily with high doses of GM-CSF (doses of $225 \mu \mathrm{g} / \mathrm{d}$ or higher in melanoma patients) [84]. In a trial of a multipeptide melanoma vaccine, immune responses were lower with GMCSF plus IFA than with IFA alone (the dose used in that trial was arguably less than $20 \mu \mathrm{g} /$ day) [81]. Thus, even low doses of GM-CSF administered with a multipeptide vaccine may have negative immunologic effects. Additional studies are also needed to determine if GM-CSF alters the function of vaccine-induced $\mathrm{T}$ cells and whether inclusion of GM-CSF with the vaccine may affect clinical outcome.

\section{Novel strategies incorporating GM-CSF GM-CSF-expressing oncolytic immunotherapy}

Preclinical studies have indicated an important role for GM-CSF in the tumor microenvironment and have suggested that increased expression of GM-CSF can inhibit tumor growth. However, administration of exogenous recombinant GM-CSF appears insufficient to mediate clinically meaningful improvements in outcomes in most instances. Consequently, there has been significant interest in novel treatment approaches incorporating GMCSF.

Among the most extensively evaluated agents is the attenuated, oncolytic, herpes simplex virus, type 1 (HSV-1)-encoding human GM-CSF talimogene laherparepvec (T-VEC; formerly Oncovex ${ }^{\mathrm{GM}-\mathrm{CSF}}$ ) [85-88]. The vector was generated from the HSV JS1 strain and was attenuated by functional deletion of the ICP34.5 and ICP47 viral genes, which renders the virus nonpathogenic in normal eukaryotic cells, promotes selective replication in tumor cells, and enhances immunogenicity [26] T-VEC has also been engineered to encode human GM-CSF, which further enhances the antitumor immune response. T-VEC is proposed to have a dual mechanism of action resulting in local tumor destruction by 


\begin{tabular}{|c|c|c|c|c|c|c|c|}
\hline Citation & $\begin{array}{l}\text { Design } \\
\text { (Enrollment) }\end{array}$ & Ag (Route) & GM-CSF form (Route) & $\begin{array}{l}\text { Coadmin- } \\
\text { istration? }\end{array}$ & Study design & Effect of GM-CSF & $\begin{array}{l}\text { Summary } \\
\text { effect of } \\
\text { GM-CSF }\end{array}$ \\
\hline \multirow[t]{5}{*}{ Scheibenbogen et al. [75] } & \multirow{5}{*}{$\begin{array}{l}\text { Sequential } \\
\text { cohorts } \\
(n=43)\end{array}$} & \multirow{5}{*}{$\begin{array}{l}\text { Tyrosinase } \\
\text { peptides (ID/SC) }\end{array}$} & \multirow{5}{*}{$\begin{array}{l}\text { Protein (ID/SC) } \\
75 \mu \mathrm{g} / \mathrm{d} \times 4 \mathrm{~d} / \text { vaccine }\end{array}$} & \multirow[t]{5}{*}{ Yes } & Sequential: & \multirow{5}{*}{ 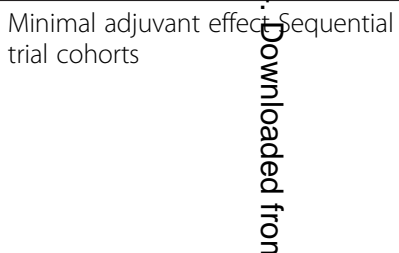 } & \multirow[t]{5}{*}{ Minimal adjuvant effect } \\
\hline & & & & & 1. Peptides alone & & \\
\hline & & & & & 2. Peptides + GM-CSF & & \\
\hline & & & & & 3. Peptides + KLH & & \\
\hline & & & & & 4. Peptides + GM-CSF + KLH & & \\
\hline \multirow[t]{3}{*}{ Slingluff et al. [81] } & \multirow{3}{*}{$\begin{array}{l}\text { Randomized } \\
(\mathrm{n}=121)\end{array}$} & \multirow{3}{*}{$\begin{array}{l}\text { Melanoma } \\
\text { peptides (ID/SC) }\end{array}$} & \multirow{3}{*}{$\begin{array}{l}\text { Protein } 110 \mu \mathrm{g} \\
\text { (ID/SC) }\end{array}$} & \multirow[t]{3}{*}{ Yes } & Randomized: & \multirow{3}{*}{ 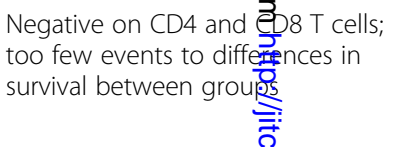 } & \multirow{3}{*}{$\begin{array}{l}\text { Diminished, compared } \\
\text { with IFA }\end{array}$} \\
\hline & & & & & 1. Peptides + IFA & & \\
\hline & & & & & 2. Peptides + IFA + GM-CSF & & \\
\hline \multirow[t]{3}{*}{ Faries et al. [71] } & \multirow{3}{*}{$\begin{array}{l}\text { Randomized } \\
(n=97)\end{array}$} & \multirow{3}{*}{$\begin{array}{l}\text { Whole melanoma } \\
\text { cell vaccine (ID) }\end{array}$} & \multirow{3}{*}{$\begin{array}{l}\text { Protein } 200 \mu \mathrm{g} / \mathrm{m}^{2} / \mathrm{d} \times 5 \\
\text { days (ID) }\end{array}$} & \multirow[t]{3}{*}{ Yes } & Randomized: & \multirow{3}{*}{ 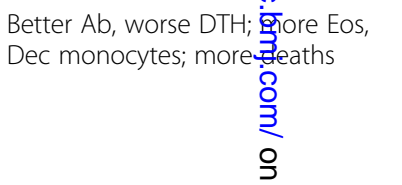 } & \multirow{3}{*}{$\begin{array}{l}\text { Diminished compared } \\
\text { with BCG }\end{array}$} \\
\hline & & & & & $\begin{array}{l}\text { 1. Whole cell vaccine + BCG } \\
+ \text { GM-CSF }\end{array}$ & & \\
\hline & & & & & 2. Whole cell vaccine + BCG & & \\
\hline \multirow[t]{5}{*}{ Kirkwood et al. [78] } & \multirow{5}{*}{$\begin{array}{l}2 \times 2 \\
(n=120)\end{array}$} & \multirow{5}{*}{$\begin{array}{l}\text { MART-1, gp100, } \\
\text { and tyrosinase } \\
\text { peptides (SC) }\end{array}$} & \multirow{5}{*}{$\begin{array}{l}250 \mu \mathrm{g} / \mathrm{d} \times 14 \text { out } \\
\text { of } 28 \text { days }\end{array}$} & \multirow[t]{5}{*}{ Yes } & $2 \times 2$ & \multirow{5}{*}{$\begin{array}{l}\text { No effect across treatment arms } \\
\text { on best overall respon高. }\end{array}$} & \multirow[t]{5}{*}{ Minimal adjuvant effect } \\
\hline & & & & & $\begin{array}{l}\text { Arm A: Peptide Vaccine } \\
\text { Alone }\end{array}$ & & \\
\hline & & & & & $\begin{array}{l}\text { Arm B: GM-CSF }(250 \mu \mathrm{g} / \mathrm{d} x \\
14 \text { out of } 28 \mathrm{~d})+ \text { vaccine }\end{array}$ & & \\
\hline & & & & & Arm C: IFN- $a+$ vaccine & & \\
\hline & & & & & $\begin{array}{l}\text { Arm D: GM-CSF + IFN-a + } \\
\text { vaccine }\end{array}$ & & \\
\hline \multicolumn{6}{|c|}{$\mathrm{ID}=$ intradermal; SC = subcutaneous; IFA = incomplete Freund's adjuvant; $\mathrm{BCG}=$ Bacille Calmette-Guerin. } & 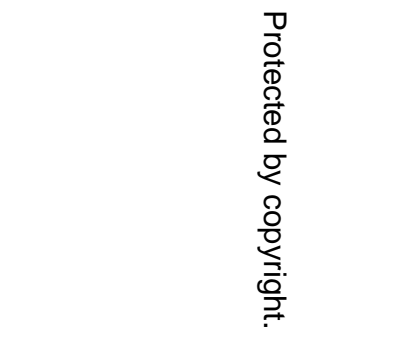 & \\
\hline
\end{tabular}


introduction of an oncolytic virus into tumor cells and induction of a systemic antitumor immune response.

In a phase 1 study, patients with subcutaneous or cutaneous metastases from breast, gastrointestinal, head and neck, or melanoma malignancies were treated with T-VEC. Clinically stable disease was noted in $3 / 26$ patients administered intralesional T-VEC, with no patients having CR or PR during the study period [86]. However, follow-up biopsies in 14/19 patients showed necrosis, infiltration of $\mathrm{T}$ cells, and the presence of replicating virus [86]. Notably, there was evidence of expression of GM-CSF in injected lesions. In a subsequent phase 2 study among 50 patients with unresectable stage IIIC/IV melanoma administered intralesional T-VEC, the overall response rate was $26 \%$ (8 CR, 5 PR) [88]. Two additional patients were rendered disease-free by surgical resection following treatment. One-year survival was $58 \%$ for all patients and $40 \%$ among patients with stage IVM1c disease. Immunologic analysis of a subset of patients enrolled in the phase 2 study confirmed the presence of both local and distant antitumor immune responses following T-VEC administration. Biopsies performed on 11 patients after their sixth intratumoral injection were compared to nonstudy patients with metastatic melanoma [87]. In general, postvaccination tumors demonstrated extensive lymphocyte infiltration. Evaluation of both injected and noninjected lesions in T-VEC-treated patients revealed a significant increase in MART-1-specific T-cell response in both tumor and distant disease sites compared with unvaccinated controls. Regulatory CD4+FoxP3+ and suppressor CD8+FoxP3+ $\mathrm{T}$ cells and myeloid-derived suppressor cells were evaluated in injected tumor biopsies and found to be decreased when compared to unvaccinated control patients. When primary injected lesions were compared to distant noninjected lesions, the same general phenotypic pattern of effector T-cell and Treg infiltrates was seen; a greater number of CD4+FoxP3+ and CD8+FoxP3+ cells were present at the nontarget site than at the target sites. A randomized, phase 3 study, OPTiM, comparing intralesional T-VEC to subcutaneous GM-CSF demonstrated an improvement in durable response rate ( $16 \%$ vs $2 \%$, respectively) and a trend toward improved OS at interim analysis (HR, 0.79 [95\% CI, 0.61-1.02]) favoring the T-VEC arm [89]. The most frequently occurring adverse events were fatigue, chills, and pyrexia [89].

\section{Systemic combination immunotherapy}

GM-CSF has also been combined with ipilimumab, an anti-CTLA-4 monoclonal antibody. In a multicenter, phase 2 study, patients with metastatic melanoma were randomized to treatment with ipilimumab plus GM-CSF (250 $\mu \mathrm{g} / \mathrm{d}$ subcutaneously for 14 days in 21 -day cycles) or ipilimumab alone [90]. Patients receiving combination therapy experienced a significant improvement in 1-year OS. Although there were no significant differences in overall toxicity between the treatment arms, patients receiving combination therapy had a lower rate of serious adverse events.

Several other approaches utilizing GM-CSF are being developed. These include an oncolytic vaccinia virus encoding GM-CSF [91], autologous dendritic cells and allogeneic whole tumor cells encoding GM-CSF [92-94], adjuvant GM-CSF following vaccination with peptide or RNA encoding melanoma peptides [95,96] and autologous dendritic cell or whole tumor cell vaccines [97], and GM-CSF DNA vaccines [98].

\section{Conclusions}

GM-CSF has been studied extensively in murine models and in human clinical trials, alone and as adjuvant therapy for melanoma. There is evidence from numerous studies that GM-CSF can induce antitumor immunity when administered by a variety of different routes. Although there was initial enthusiasm for recombinant GM-CSF based on uncontrolled clinical trials in stage III/IV melanoma, therapeutic benefit has not been confirmed in larger, prospective, randomized trials. The adjuvant or combination use of GM-CSF has been more promising although results have been inconsistent and may depend on the potency of the immunotherapy regimen, GM-CSF dose, route and schedule of administration, and stage of disease. There is emerging evidence that GM-CSF may be a regulatory cytokine with the ability to promote both effector and regulatory/suppressor $\mathrm{T}$ cell populations. Thus, strategies that block suppressor $\mathrm{T}$ cell and myeloid-derived suppressor cell elements may enhance the antitumor activity of GM-CSF. GM-CSF has been particularly effective in studies of oncolytic HSV therapy of melanoma and in combination with ipilimumab. Further research into the basic biology of GM-CSF on effector and suppressor immune cells and expanded clinical studies of combination treatments will help define the full therapeutic potential of GM-CSF in treatment of melanoma.

\section{Abbreviations \\ CTLA-4: Cytotoxic T-lymphocyte antigen 4; CR: Complete response; DC: Dendritic cells; DFS: Disease-free survival; GM-CSF: Granulocyte-macrophage colony-stimulating factor; HR: Hazard ratio; HSV: Herpes simplex viruses; IFA: Incomplete Freund's adjuvant; KLH: Keyhole limpet hemocyanin; MDSC: Myeloid-derived suppressor cells; OS: Overall survival; PD-1: Programmed death 1; PR: Partial response; T-VEC: Talimogene laherparepvec.}

\section{Competing interests}

HLK serves as a paid consultant and advisory board member for Amgen Inc. CLS is a scientific advisory board member for Immatics Biotechnologies and Polynoma LLC and a funded investigator for GlaxoSmithKline in the field of cancer vaccines; all funds from these activities are paid to the University of Virginia, not to Dr. Slingluff personally. Dr. Slingluff is an inventor on several patents for peptides used in cancer vaccines; the patents are held by the 
University of Virginia Licensing and Ventures Group. CER and TH have no conflicts to declare.

\section{Authors' contributions}

All authors participated in critical analysis of the literature and drafting of the manuscript. All authors read and approved the final manuscript.

\section{Acknowledgment}

The authors would like to thank Erica S. Chevalier-Larsen, PhD (Complete Healthcare Communications, Inc., Chadds Ford, PA), for assistance in the preparation of this manuscript which was funded by Amgen Inc.

\section{Author details}

${ }^{1}$ Rutgers Cancer Institute of New Jersey, 195 Little Albany Street, New Brunswick, NJ 08901, USA. ${ }^{2}$ Rush University Medical Center, 600 S Paulina St Suite 527, Chicago, IL 60612, USA. ${ }^{3}$ University of Virginia, P.O. Box 800709 , Charlottesville, VA 22908, USA.

Received: 27 January 2014 Accepted: 25 March 2014

Published: 13 May 2014

\section{References}

1. Siegel R, Naishadham D, Jemal A: Cancer statistics, 2012. CA Cancer J Clin 2012, 62:10-29.

2. National Comprehensive Cancer Network: NCCN Guidelines ${ }^{\circledR}$ Version 2.2013 Melanoma. Fort Washington, PA: 2012

3. Pandolfi F, Cianci R, Pagliari D, Casciano F, Bagala C, Astone A, Landolfi R, Barone $C$ : The immune response to tumors as a tool toward immunotherapy. Clin Dev Immunol 2011, 2011:894704

4. Eggermont AM, Suciu S, Santinami M, Testori A, Kruit WH, Marsden J, Punt CJ, Sales F, Gore M, Mackie R, Kusic Z, Dummer R, Hauschild A, Musat E, Spatz A, Keilholz U, Group EM: Adjuvant therapy with pegylated interferon alfa-2b versus observation alone in resected stage III melanoma: final results of EORTC 18991, a randomised phase III trial. Lancet 2008, 372:117-126.

5. Hodi FS, O'Day SJ, McDermott DF, Weber RW, Sosman JA, Haanen JB, Gonzalez R, Robert C, Schadendorf D, Hassel JC, Akerley W, van den Eertwegh AJ, Lutzky J, Lorigan P, Vaubel JM, Linette GP, Hogg D, Ottensmeier CH, Lebbe C, Peschel C, Quirt I, Clark JI, Wolchok JD, Weber JS, Tian J, Yellin MJ, Nichol GM, Hoos A, Urba WJ: Improved survival with ipilimumab in patients with metastatic melanoma. N Engl J Med 2010, 363:711-723.

6. Robert C, Thomas L, Bondarenko I, O'Day S, DJ M, Garbe C, Lebbe C, Baurain JF, Testori A, Grob JJ, Davidson N, Richards J, Maio M, Hauschild A, Miller WH Jr, Gascon P, Lotem M, Harmankaya K, Ibrahim R, Francis S, Chen TT, Humphrey R, Hoos A, Wolchok JD: Ipilimumab plus dacarbazine for previously untreated metastatic melanoma. N Engl J Med 2011, 364:2517-2526.

7. Atkins MB, Lotze MT, Dutcher JP, Fisher RI, Weiss G, Margolin K, Abrams J, Sznol M, Parkinson D, Hawkins M, Paradise C, Kunkel L, Rosenberg SA: High-dose recombinant interleukin 2 therapy for patients with metastatic melanoma: analysis of 270 patients treated between 1985 and 1993. J Clin Oncol 1999, 17:2105-2116.

8. Rosenberg SA, Yang JC, Sherry RM, Kammula US, Hughes MS, Phan GQ, Citrin DE, Restifo NP, Robbins PF, Wunderlich JR, Morton KE, Laurencot CM Steinberg SM, White DE, Dudley ME: Durable complete responses in heavily pretreated patients with metastatic melanoma using T-cell transfer immunotherapy. Clin Cancer Res 2011, 17:4550-4557.

9. Metcalf D: Hematopoietic cytokines. Blood 2008, 111:485-491.

10. Hercus TR, Thomas D, Guthridge MA, Ekert PG, King-Scott J, Parker MW, Lopez AF: The granulocyte-macrophage colony-stimulating factor receptor: linking its structure to cell signaling and its role in disease. Blood 2009, 114:1289-1298.

11. Dranoff G, Jaffee E, Lazenby A, Golumbek P, Levitsky H, Brose K, Jackson V, Hamada H, Pardoll D, Mulligan RC: Vaccination with irradiated tumor cells engineered to secrete murine granulocyte-macrophage colony-stimulating factor stimulates potent, specific, and long-lasting anti-tumor immunity. Proc Natl Acad Sci USA 1993, 90:3539-3543.

12. Lonial S, Akhtari M, Kaufman J, Torre C, Lechowicz MJ, Flowers C, Sinha R, Khoury HJ, Langston AA, Waller EK: Mobilization of hematopoietic progenitors from normal donors using the combination of granulocyte- macrophage colony-stimulating factor and granulocyte colonystimulating factor results in fewer plasmacytoid dendritic cells in the graft and enhanced donor T cell engraftment with Th1 polarization: results from a randomized clinical trial. Biol Blood Marrow Transplant 2013, 19:460-467

13. Lonial S, Hicks M, Rosenthal H, Langston A, Redei I, Torre C, Duenzl M, Feinstein B, Cherry J, Waller EK: A randomized trial comparing the combination of granulocyte-macrophage colony-stimulating factor plus granulocyte colony-stimulating factor versus granulocyte colonystimulating factor for mobilization of dendritic cell subsets in hematopoietic progenitor cell products. Biol Blood Marrow Transplant 2004, 10:848-857.

14. Mach N, Gillessen S, Wilson SB, Sheehan C, Mihm M, Dranoff G: Differences in dendritic cells stimulated in vivo by tumors engineered to secrete granulocyte-macrophage colony-stimulating factor or Flt3-ligand. Cancer Res 2000, 60:3239-3246.

15. Choudhury BA, Liang JC, Thomas EK, Flores-Romo L, Xie QS, Agusala K Sutaria S, Sinha I, Champlin RE, Claxton DF: Dendritic cells derived in vitro from acute myelogenous leukemia cells stimulate autologous, antileukemic T-cell responses. Blood 1999, 93:780-786.

16. Boyer MW, Waller EK, Bray RA, Unangst T, Johnson TS, Phillips C, Jurickova I, Winton EF, Yeager AM: Cytokine upregulation of the antigen presenting function of acute myeloid leukemia cells. Leukemia 2000, 14:412-418.

17. Leukine ${ }^{\circledast}$ (sargramostim): Full Prescribing Information. Cambridge, MA: Genzyme Corporation; 2009.

18. Ahlers JD, Dunlop N, Alling DW, Nara PL, Berzofsky JA: Cytokine-in-adjuvant steering of the immune response phenotype to HIV-1 vaccine constructs: granulocyte-macrophage colony-stimulating factor and TNF-alpha synergize with IL-12 to enhance induction of cytotoxic T lymphocytes. J Immunol 1997, 158:3947-3958.

19. Reilly RT, Gottlieb MB, Ercolini AM, Machiels JP, Kane CE, Okoye Fl, Muller WJ, Dixon KH, Jaffee EM: HER-2/neu is a tumor rejection target in tolerized HER-2/neu transgenic mice. Cancer Res 2000, 60:3569-3576.

20. Reilly RT, Machiels JP, Emens LA, Ercolini AM, Okoye Fl, Lei RY, Weintraub D, Jaffee EM: The collaboration of both humoral and cellular HER-2/neutargeted immune responses is required for the complete eradication of HER-2/neu-expressing tumors. Cancer Res 2001, 61:880-883.

21. Borrello I, Pardoll D: GM-CSF-based cellular vaccines: a review of the clinical experience. Cytokine Growth Factor Rev 2002, 13:185-193.

22. Simmons AD, Li B, Gonzalez-Edick M, Lin C, Moskalenko M, Du T, Creson J, VanRoey MJ, Jooss K: GM-CSF-secreting cancer immunotherapies: preclinical analysis of the mechanism of action. Cancer Immunol Immunother 2007, 56:1653-1665.

23. Ju DW, Cao X, Acres B: Active specific immunotherapy of pulmonary metastasis with vaccinia melanoma oncolysate prepared from granulocyte/macrophage-colony-stimulating-factor-gene-encoded vaccinia virus. J Cancer Res Clin Oncol 1996, 122:716-722.

24. Ju DW, Cao X, Acres B: Intratumoral injection of GM-CSF gene encoded recombinant vaccinia virus elicits potent antitumor response in a mixture melanoma model. Cancer Gene Ther 1997, 4:139-144.

25. Toda M, Martuza RL, Rabkin SD: Tumor growth inhibition by intratumoral inoculation of defective herpes simplex virus vectors expressing granulocytemacrophage colony-stimulating factor. Mol Ther 2000, 2:324-329.

26. Liu BL, Robinson M, Han ZQ, Branston RH, English C, Reay P, McGrath Y, Thomas SK, Thornton M, Bullock P, Love CA, Coffin RS: ICP34.5 deleted herpes simplex virus with enhanced oncolytic, immune stimulating, and anti-tumour properties. Gene Ther 2003, 10:292-303.

27. Li B, VanRoey M, Wang C, Chen TH, Korman A, Jooss K: Anti-programmed death-1 synergizes with granulocyte macrophage colony-stimulating factor-secreting tumor cell immunotherapy providing therapeutic benefit to mice with established tumors. Clin Cancer Res 2009, 15:1623-1634.

28. Quezada SA, Peggs KS, Curran MA, Allison JP: CTLA4 blockade and GM-CSF combination immunotherapy alters the intratumor balance of effector and regulatory T cells. J Clin Invest 2006, 116:1935-1945.

29. Topalian SL, Hodi FS, Brahmer JR, Gettinger SN, Smith DC, McDermott DF, Powderly JD, Carvajal RD, Sosman JA, Atkins MB, Leming PD, Spigel DR, Antonia SJ, Horn L, Drake CG, Pardoll DM, Chen L, Sharfman WH, Anders RA, Taube JM, McMiller TL, Xu H, Korman AJ, Jure-Kunkel M, Agrawal S, McDonald D, Kollia GD, Gupta A, Wigginton JM, Sznol M: Safety, activity, and immune correlates of anti-PD-1 antibody in cancer. $N$ Engl J Med 2012, 366:2443-2454 
30. van Elsas A, Hurwitz AA, Allison JP: Combination immunotherapy of B16 melanoma using anti-cytotoxic T lymphocyte-associated antigen 4 (CTLA-4) and granulocyte/macrophage colony-stimulating factor (GM-CSF)-producing vaccines induces rejection of subcutaneous and metastatic tumors accompanied by autoimmune depigmentation. J Exp Med 1999, 190:355-366.

31. Weber J: Immune checkpoint proteins: a new therapeutic paradigm for cancer-preclinical background: CTLA-4 and PD-1 blockade. Semin Oncol 2010, 37:430-439.

32. Choi KJ, Kim JH, Lee YS, Kim J, Suh BS, Kim H, Cho S, Sohn JH, Kim GE, Yun $\mathrm{CO}$ : Concurrent delivery of GM-CSF and B7-1 using an oncolytic adenovirus elicits potent antitumor effect. Gene Ther 2006, 13:1010-1020.

33. Li B, Lin J, Vanroey M, Jure-Kunkel M, Jooss K: Established B16 tumors are rejected following treatment with GM-CSF-secreting tumor cell immunotherapy in combination with anti-4-1BB mAb. Clin Immunol 2007 125:76-87.

34. Prell RA, Li B, Lin JM, VanRoey M, Jooss K: Administration of IFN-alpha enhances the efficacy of a granulocyte macrophage colony stimulating factor-secreting tumor cell vaccine. Cancer Res 2005, 65:2449-2456.

35. Stagg J, Wu JH, Bouganim N, Galipeau J: Granulocyte-macrophage colonystimulating factor and interleukin-2 fusion cDNA for cancer gene immunotherapy. Cancer Res 2004, 64:8795-8799.

36. Li B, Lalani AS, Harding TC, Luan B, Koprivnikar K, Huan Tu G, Prell R, VanRoey MJ, Simmons AD, Jooss K: Vascular endothelial growth factor blockade reduces intratumoral regulatory $T$ cells and enhances the efficacy of a GM-CSF-secreting cancer immunotherapy. Clin Cancer Res 2006, 12:6808-6816.

37. Spitler LE, Grossbard ML, Ernstoff MS, Silver G, Jacobs M, Hayes FA, Soong SJ: Adjuvant therapy of stage III and IV malignant melanoma using granulocyte-macrophage colony-stimulating factor. J Clin Oncol 2000, 18:1614-1621

38. Spitler LE, Weber RW, Allen RE, Meyer J, Cruickshank S, Garbe E, Lin HY, Soong SJ: Recombinant human granulocyte-macrophage colonystimulating factor (GM-CSF, sargramostim) administered for 3 years as adjuvant therapy of stages II(T4), III, and IV melanoma. J Immunother 2009, 32:632-637.

39. Daud Al, Mirza N, Lenox B, Andrews S, Urbas P, Gao GX, Lee JH, Sondak VK Riker Al, Deconti RC, Gabrilovich D: Phenotypic and functional analysis of dendritic cells and clinical outcome in patients with high-risk melanoma treated with adjuvant granulocyte macrophage colony-stimulating factor. J Clin Oncol 2008, 26:3235-3241.

40. Lawson DH, Lee SJ, Tarhini AA, Margolin KA, Ernstoff MS, Kirkwood JM: E4697: Phase III cooperative group study of yeast-derived granulocyte macrophage colonystimulating factor (GM-CSF) versus placebo as adjuvant treatment of patients with completely resected stage III-IV melanoma. J Clin Oncol 2010, 28:abstr 8504.

41. Markovic S, Burch PA, LaPlant B, Heun JM, Bradshaw R: Adjuvant GM-CSF therapy for patients with resected stage III/IV melanoma: A retrospective review of a single-center experience. J Clin Oncol 2011, 29:abstr 8596

42. Isla D, Filipovich E, Mayordomo JI, Andres R, Puig S, Escudero MP, Gallego O, Trujillo R, Revenga F, Alvarez I, Saenz A, Polo E, Tres A: Daily GM-CSF for patients with very high-risk resected melanoma: a pilot trial. Proc Am Soc Clin Oncol 2002, 21:abstr 2784.

43. Elias EG, Zapas JL, McCarron EC, Beam SL, Hasskamp JH, Culpepper WJ: Sequential administration of GM-CSF (Sargramostim) and IL-2 +/autologous vaccine as adjuvant therapy in cutaneous melanoma: an interim report of a phase II clinical trial. Cancer Biother Radiopharm 2008 23:285-291.

44. Si Z, Hersey P, Coates AS: Clinical responses and lymphoid infiltrates in metastatic melanoma following treatment with intralesional GM-CSF. Melanoma Res 1996, 6:247-255.

45. Nasi ML, Lieberman P, Busam KJ, Prieto V, Panageas KS, Lewis JJ, Houghton AN, Chapman PB: Intradermal injection of granulocyte-macrophage colony-stimulating factor (GM-CSF) in patients with metastatic melanoma recruits dendritic cells. Cytokines Cell Mol Ther 1999, 5:139-144.

46. Hoeller C, Jansen B, Heere-Ress E, Pustelnik T, Mossbacher U, Schlagbauer-Wad $\mathrm{H}$, Wolff K, Pehamberger $\mathrm{H}$ : Perilesional injection of $\mathrm{r}$-GM-CSF in patients with cutaneous melanoma metastases. J Invest Dermatol 2001, 117:371-374.

47. Rao RD, Anderson PM, Arndt CA, Wettstein PJ, Markovic SN: Aerosolized granulocyte macrophage colony-stimulating factor (GM-CSF) therapy in metastatic cancer. Am J Clin Oncol 2003, 26:493-498.
48. Markovic SN, Suman VJ, Nevala WK, Geeraerts L, Creagan ET, Erickson LA, Rowland KM Jr, Morton RF, Horvath WL, Pittelkow MR: A dose-escalation study of aerosolized sargramostim in the treatment of metastatic melanoma: an NCCTG Study. Am J Clin Oncol 2008, 31:573-579.

49. Sato T, Eschelman DJ, Gonsalves CF, Terai M, Chervoneva I, McCue PA, Shields JA, Shields CL, Yamamoto A, Berd D, Mastrangelo MJ, Sullivan KL: Immunoembolization of malignant liver tumors, including uveal melanoma, using granulocyte-macrophage colony-stimulating factor. J Clin Oncol 2008, 26:5436-5442.

50. Eschelman DJ, Gonsalves CF, Terai M, Laudadio M, Sullivan KL, Mastrangelo MJ, Sato T: The results of a randomized phase II study using embolization with or without granulocyte-macrophage colonystimulating factor (GM-CSF) in uveal melanoma patients with hepatic metastasis. J Clin Oncol 2011, 29:abstr 8577.

51. Vaquerano JE, Cadbury P, Treseler P, Sagebiel R, Leong SP: Regression of in-transit melanoma of the scalp with intralesional recombinant human granulocyte-macrophage colony-stimulating factor. Arch Dermatol 1999, 135:1276-1277.

52. Ridolfi L, Ridolfi R: Preliminary experiences of intralesional immunotherapy in cutaneous metastatic melanoma. Hepatogastroenterology 2002,49:335-339.

53. Schachter J, Rakowsky E, Sulkes A, Adler A: A sequential four-drug chemotherapy and biotherapy with interferon alpha and GM-CSF-an innovative protocol for the treatment of metastatic melanoma. Cancer Biother Radiopharm 1998, 13:155-164.

54. Fruehauf JP, Kong KM, Jakowatz JG: Docetaxel and vinorelbine plus GMCSF in malignant melanoma. Oncology (Williston Park) 2005, 19:19-22.

55. Jin S, Zhang Q, Kang X, Wang J, Sun W: Malignant melanoma therapy by chemotherapy and autoimmunity induced by cytokine. Cancer Biother Radiopharm 2009, 24:237-241.

56. O'Day SJ, Atkins MB, Boasberg P, Wang HJ, Thompson JA, Anderson CM, Gonzalez R, Lutzky J, Amatruda T, Hersh EM, Weber JS: Phase II multicenter trial of maintenance biotherapy after induction concurrent Biochemotherapy for patients with metastatic melanoma. J Clin Oncol 2009, 27:6207-6212.

57. Locke F, Clark JI, Gajewski TF: A phase II study of oxaliplatin, docetaxel, and GM-CSF in patients with previously treated advanced melanoma. Cancer Chemother Pharmacol 2010, 65:509-514.

58. Lutzky J, Weber R, Nunez Y, Gillett M, Spitler L: A phase 1 study of granulocyte macrophage colony-stimulating factor (sargramostim) and escalating doses of thalidomide in patients with high-risk malignant melanoma. J Immunother 2009, 32:79-85.

59. Vaughan MM, Moore J, Riches PG, Johnston SR, A'Hern RP, Hill ME, Eisen T, Ayliffe MJ, Thomas JM, Gore ME: GM-CSF with biochemotherapy (cisplatin, DTIC, tamoxifen, IL-2 and interferon-alpha): a phase I trial in melanoma. Ann Oncol 2000, 11:1183-1189.

60. Gajewski T, Flickinger S: A phase II study of outpatient chemoimmunotherapy using cisplatin and DTIC followed by GM-CSF, $\mathrm{IL}-2$, and IFN-2b in patients (pts) with metastatic melanoma. Proc Am Soc Clin Oncol 2000, 19:abstr 2271.

61. Gibbs P, O'Day S, Richards J, Weber J, Anderson C, Gonzalez R: Biochemotherapy (BCT) for stage IV melanoma incorporating temozolomide, decrescendo interleukin-2 (IL-2) and GM-CSF. Proc Am Soc Clin Oncol 2000, 19:2255

62. Gong I-Y, Swiger S, Gajewski T: Integration of GM-CSF into outpatient chemoimmunotherapy for metastatic melanoma. Proc Am Soc Clin Oncol 2002, 21:2790

63. Groenewegen G, Bloem A, De Gast GC: Phase I/II study of sequential chemoimmunotherapy (SCIT) for metastatic melanoma: outpatient treatment with dacarbazine, granulocyte-macrophage colonystimulating factor, low-dose interleukin-2, and interferon-alpha. Cancer Immunol Immunother 2002, 51:630-636.

64. de Gast GC, Batchelor D, Kersten MJ, Vyth-Dreese FA, Sein J, van de Kasteele WF, Nooijen WJ, Nieweg OE, de Waal MA, Boogerd W: Temozolomide followed by combined immunotherapy with GM-CSF, low-dose IL2 and IFN alpha in patients with metastatic melanoma. Br J Cancer 2003, 88:175-180.

65. Smith IJ, Kurt RA, Baher AG, Denman S, Justice L, Doran T, Gilbert M, Alvord WG, Urba WJ: Immune effects of escalating doses of granulocytemacrophage colony-stimulating factor added to a fixed, low-dose, inpatient interleukin- 2 regimen: a randomized phase I trial in patients 
with metastatic melanoma and renal cell carcinoma. J Immunother 2003, 26:130-138.

66. Lewis KD, Gibbs P, O'Day S, Richards J, Weber J, Anderson C, Zeng C, Baron A, Russ P, Gonzalez R: A phase II study of biochemotherapy for advanced melanoma incorporating temozolomide, decrescendo interleukin-2 and GM-CSF. Cancer Invest 2005, 23:303-308.

67. Weber RW, O'Day S, Rose M, Deck R, Ames P, Good J, Meyer J, Allen R, Trautvetter S, Timmerman M, Cruickshank S, Cook M, Gonzalez R, Spitler LE: Low-dose outpatient chemobiotherapy with temozolomide, granulocytemacrophage colony stimulating factor, interferon-alpha $2 b$, and recombinant interleukin-2 for the treatment of metastatic melanoma. J Clin Oncol 2005, 23:8992-9000.

68. Gunturu KS, Meehan KR, Mackenzie TA, Crocenzi TS, McDermott D, Usherwood EJ, Margolin KA, Crosby NA, Atkins MB, Turk MJ, Ahonen C, Fuse S, Clark Jl, Fisher JL, Noelle RJ, Ernstoff MS: Cytokine working group study of lymphodepleting chemotherapy, interleukin-2, and granulocytemacrophage colony-stimulating factor in patients with metastatic melanoma: clinical outcomes and peripheral-blood cell recovery. J Clin Oncol 2010, 28:1196-1202

69. Lutzky J, Lawson DH, Enriquez-Nunez Y, Gabrilovich D: Phase II trial of high-dose interleukin-2 (IL-2) with priming and concomitant sargramostim (GM-CSF) in patients with advanced melanoma. J Clin Oncol 2010, 28:abstr 8560

70. Ali OA, Emerich D, Dranoff G, Mooney DJ: In situ regulation of DC subsets and T cells mediates tumor regression in mice. Sci Transl Med 2009, 1:8ra19.

71. Faries MB, Hsueh EC, Ye X, Hoban M, Morton DL: Effect of granulocyte/ macrophage colony-stimulating factor on vaccination with an allogeneic whole-cell melanoma vaccine. Clin Cancer Res 2009, 15:7029-7035.

72. Slingluff CL Jr, Petroni GR, Yamshchikov GV, Barnd DL, Eastham S, Galavotti H, Patterson JW, Deacon DH, Hibbitts S, Teates D, Neese PY, Grosh WW, Chianese-Bullock KA, Woodson EM, Wiernasz CJ, Merrill P, Gibson J, Ross M, Engelhard $\mathrm{VH}$ : Clinical and immunologic results of a randomized phase II trial of vaccination using four melanoma peptides either administered in granulocyte-macrophage colony-stimulating factor in adjuvant or pulsed on dendritic cells. J Clin Oncol 2003, 21:4016-4026.

73. Walter S, Weinschenk T, Stenzl A, Zdrojowy R, Pluzanska A, Szczylik C, Staehler M, Brugger W, Dietrich PY, Mendrzyk R, Hilf N, Schoor O, Fritsche J, Mahr A, Maurer D, Vass V, Trautwein C, Lewandrowski P, Flohr C, Pohla H, Stanczak JJ, Bronte V, Mandruzzato S, Biedermann T, Pawelec G, Derhovanessian E, Yamagishi H, Miki T, Hongo F, Takaha N, et al: Multipeptide immune response to cancer vaccine IMA901 after singledose cyclophosphamide associates with longer patient survival. Nat Med 2012, 18:1254-1261.

74. Chianese-Bullock KA, Pressley J, Garbee C, Hibbitts S, Murphy C, Yamshchikov G, Petroni GR, Bissonette EA, Neese PY, Grosh WW, Merrill P, Fink R, Woodson EM, Wiernasz CJ, Patterson JW, Slingluff CL Jr: MAGE-A1-, MAGE-A10-, and gp100-derived peptides are immunogenic when combined with granulocyte-macrophage colony-stimulating factor and montanide ISA-51 adjuvant and administered as part of a multipeptide vaccine for melanoma. J Immunol 2005, 174:3080-3086.

75. Scheibenbogen C, Schadendorf D, Bechrakis NE, Nagorsen D, Hofmann U, Servetopoulou F, Letsch A, Philipp A, Foerster MH, Schmittel A, Thiel E, Keilholz U: Effects of granulocyte-macrophage colony-stimulating factor and foreign helper protein as immunologic adjuvants on the T-cell response to vaccination with tyrosinase peptides. Int J Cancer 2003, 104:188-194.

76. Scheibenbogen C, Schmittel A, Keilholz U, Allgauer T, Hofmann U, Max R, Thiel E, Schadendorf D: Phase 2 trial of vaccination with tyrosinase peptides and granulocyte-macrophage colony-stimulating factor in patients with metastatic melanoma. J Immunother 2000, 23:275-281.

77. Jager E, Ringhoffer M, Dienes HP, Arand M, Karbach J, Jager D, Ilsemann C, Hagedorn M, Oesch F, Knuth A: Granulocyte-macrophage-colonystimulating factor enhances immune responses to melanoma-associated peptides in vivo. Int J Cancer 1996, 67:54-62.

78. Kirkwood JM, Lee S, Moschos SJ, Albertini MR, Michalak JC, Sander C, Whiteside T, Butterfield LH, Weiner L: Immunogenicity and antitumor effects of vaccination with peptide vaccine+/-granulocyte-monocyte colony-stimulating factor and/or IFN-alpha2b in advanced metastatic melanoma: Eastern Cooperative Oncology Group Phase II Trial E1696. Clin Cancer Res 2009, 15:1443-1451.
79. Soiffer R, Hodi FS, Haluska F, Jung K, Gillessen S, Singer S, Tanabe K, Duda R, Mentzer S, Jaklitsch M, Bueno R, Clift S, Hardy S, Neuberg D, Mulligan R, Webb I, Mihm M, Dranoff G: Vaccination with irradiated, autologous melanoma cells engineered to secrete granulocyte-macrophage colonystimulating factor by adenoviral-mediated gene transfer augments antitumor immunity in patients with metastatic melanoma. J Clin Oncol 2003, 21:3343-3350.

80. Soiffer R, Lynch T, Mihm M, Jung K, Rhuda C, Schmollinger JC, Hodi FS, Liebster L, Lam P, Mentzer S, Singer S, Tanabe KK, Cosimi AB, Duda R, Sober A, Bhan A, Daley J, Neuberg D, Parry G, Rokovich J, Richards L, Drayer J, Berns A, Clift S, Cohen LK, Mulligan RC, Dranoff G: Vaccination with irradiated autologous melanoma cells engineered to secrete human granulocyte-macrophage colony-stimulating factor generates potent antitumor immunity in patients with metastatic melanoma. Proc Natl Acad Sci USA 1998, 95:13141-13146.

81. Slingluff CL Jr, Petroni GR, Olson WC, Smolkin ME, Ross MI, Haas NB, Grosh WW, Boisvert ME, Kirkwood JM, Chianese-Bullock KA: Effect of granulocyte/ macrophage colony-stimulating factor on circulating CD8+ and CD4+ T-cell responses to a multipeptide melanoma vaccine: outcome of a multicenter randomized trial. Clin Cancer Res 2009, 15:7036-7044.

82. Schaefer C, Butterfield LH, Lee S, Kim GG, Visus C, Albers A, Kirkwood JM, Whiteside TL: Function but not phenotype of melanoma peptide-specific CD8(+) T cells correlate with survival in a multiepitope peptide vaccine trial (ECOG 1696). Int J Cancer 2012, 131:874-884.

83. Filipazzi P, Valenti R, Huber V, Pilla L, Canese P, lero M, Castelli C, Mariani L, Parmiani G, Rivoltini L: Identification of a new subset of myeloid suppressor cells in peripheral blood of melanoma patients with modulation by a granulocyte-macrophage colony-stimulation factorbased antitumor vaccine. J Clin Oncol 2007, 25:2546-2553.

84. Parmiani G, Castelli C, Pilla L, Santinami M, Colombo MP, Rivoltini L: Opposite immune functions of GM-CSF administered as vaccine adjuvant in cancer patients. Ann Oncol 2007, 18:226-232.

85. Harrington KJ, Hingorani M, Tanay MA, Hickey J, Bhide SA, Clarke PM, Renouf LC, Thway K, Sibtain A, McNeish IA, Newbold KL, Goldsweig H, Coffin R, Nutting CM: Phase I/II study of oncolytic HSV GM-CSF in combination with radiotherapy and cisplatin in untreated stage III/IV squamous cell cancer of the head and neck. Clin Cancer Res 2010, 16:4005-4015

86. Hu JCC, Coffin RS, Davis CJ: A phase I study of OncoVEXGM-CSF, a second-generation oncolytic herpes simplex virus expressing granulocyte macrophage colony-stimulating factor. Clin Cancer Res 2006, 12:6737-6747.

87. Kaufman HL, Kim DW, DeRaffele G, Mitcham J, Coffin RS, Kim-Schulze S: Local and distant immunity induced by intralesional vaccination with an oncolytic herpes virus encoding GM-CSF in patients with stage IIIC and IV melanoma. Ann Surg Oncol 2010, 17:718-730.

88. Senzer NN, Kaufman HL, Amatruda T, Nemunaitis M, Reid T, Daniels G, Gonzalez R, Glaspy J, Whitman E, Harrington K, Goldsweig H, Marshall T, Love C, Coffin R, Nemunaitis JJ: Phase II clinical trial of a granulocytemacrophage colony-stimulating factor-encoding, second-generation oncolytic herpesvirus in patients with unresectable metastatic melanoma. J Clin Oncol 2009, 27:5763-5771.

89. Andtbacka RHI, Collichio FA, Amatruda T, Senzer NN, Chesney J, Delman KA, Spitler LE, Puzanov I, Doleman S, Ye Y, Vanderwalde AM, Coffin R, Kaufman H: OPTiM: A randomized phase III trial of talimogene laherparepvec (T-VEC) versus subcutaneous (SC) granulocyte-macrophage colonystimulating factor (GM-CSF) for the treatment (tx) of unresected stage IIIB/C and IV melanoma. J Clin Oncol 2013, 31:abstr LBA9008.

90. Hodi FS, Lee SJ, McDermott DF, Rao UNM, Butterfield LH, Tarhini AA Leming PD, Puzanov I, Kirkwood JM: Multicenter, randomized phase II trial of GM-CSF (GM) plus ipilimumab (Ipi) versus Ipi alone in metastatic melanoma: E1608. J Clin Oncol 2013, 31:abstr CRA9007.

91. Heo J, Breitbach CJ, Moon A, Kim CW, Patt R, Kim MK, Lee YK, Oh SY, Woo HY, Parato K, Rintoul J, Falls T, Hickman T, Rhee BG, Bell JC, Kirn DH, Hwang $\mathrm{TH}$ : Sequential therapy with JX-594, a targeted oncolytic poxvirus, followed by sorafenib in hepatocellular carcinoma: preclinical and clinical demonstration of combination efficacy. Mol Ther 2011 19:1170-1179.

92. Higano CS, Corman JM, Smith DC, Centeno AS, Steidle CP, Gittleman M, Simons JW, Sacks N, Aimi J, Small EJ: Phase 1/2 dose-escalation study of a GM-CSF-secreting, allogeneic, cellular immunotherapy for metastatic hormone-refractory prostate cancer. Cancer 2008, 113:975-984. 
93. Schoenfeld J, Jinushi M, Nakazaki Y, Wiener D, Park J, Soiffer R, Neuberg D, Mihm M, Hodi FS, Dranoff G: Active immunotherapy induces antibody responses that target tumor angiogenesis. Cancer Res 2010, 70:10150-10160.

94. Senzer N, Barve M, Kuhn J, Melnyk A, Beitsch P, Lazar M, Lifshitz S, Magee M, Oh J, Mill SW, Bedell C, Higgs C, Kumar P, Yu Y, Norvell F, Phalon C, Taquet N, Rao DD, Wang Z, Jay CM, Pappen BO, Wallraven G, Brunicardi FC, Shanahan DM, Maples PB, Nemunaitis J: Phase I trial of "bi-shRNAi(furin)/ GMCSF DNA/autologous tumor cell" vaccine (FANG) in advanced cancer. Mol Ther 2012, 20:679-686.

95. Adamina M, Rosenthal R, Weber WP, Frey DM, Viehl CT, Bolli M, Huegli RW, Jacob AL, Heberer M, Oertli D, Marti W, Spagnoli GC, Zajac P: Intranodal immunization with a vaccinia virus encoding multiple antigenic epitopes and costimulatory molecules in metastatic melanoma. Mol Ther 2010, 18:651-659

96. Weide B, Pascolo S, Scheel B, Derhovanessian E, Pflugfelder A, Eigentler TK, Pawelec G, Hoerr I, Rammensee HG, Garbe C: Direct injection of protamine-protected mRNA: results of a phase $1 / 2$ vaccination trial in metastatic melanoma patients. J Immunother 2009, 32:498-507.

97. Dillman RO, Cornforth AN, Depriest C, McClay EF, Amatruda TT, de Leon C, Ellis RE, Mayorga C, Carbonell D, Cubellis JM: Tumor stem cell antigens as consolidative active specific immunotherapy: a randomized phase II trial of dendritic cells versus tumor cells in patients with metastatic melanoma. J Immunother 2012, 35:641-649.

98. Perales MA, Yuan J, Powel S, Gallardo HF, Rasalan TS, Gonzalez C, Manukian G, Wang J, Zhang Y, Chapman PB, Krown SE, Livingston PO, Ejadi S, Panageas KS, Engelhorn ME, Terzulli SL, Houghton AN, Wolchok JD: Phase I/II study of GM-CSF DNA as an adjuvant for a multipeptide cancer vaccine in patients with advanced melanoma. Mol Ther 2008, 16:2022-2029.

doi:10.1186/2051-1426-2-11

Cite this article as: Kaufman et al.: Current status of granulocytemacrophage colony-stimulating factor in the immunotherapy of melanoma. Journal for ImmunoTherapy of Cancer 2014 2:11.

\section{Submit your next manuscript to BioMed Central and take full advantage of:}

- Convenient online submission

- Thorough peer review

- No space constraints or color figure charges

- Immediate publication on acceptance

- Inclusion in PubMed, CAS, Scopus and Google Scholar

- Research which is freely available for redistribution

Submit your manuscript at www.biomedcentral.com/submit 